SEÇÃO VARIA 


\title{
Representações da diáspora na escrita de Orlanda Amarílis
}

\author{
Elisa Maria Taborda da Silva \\ Universidade Federal de Minas Gerais \\ Maria Zilda Ferreira Cury \\ Universidade Federal de Minas Gerais
}

cabo-verdiana Orlanda Amarílis escreveu suas
narrativas fora de sua terra natal. Tal condição
marca profundamente sua obra e confere uma feição particular à sua escrita, principalmente se lembrarmos que grande parte dos cabo-verdianos partilha com ela uma condição diaspórica, exilada. Boa parte deles emigra para a Europa e Estados Unidos, para o Brasil, havendo mais caboverdianos vivendo fora de seu país natal do que na própria terra. Orlanda Amarílis Lopes Rodrigues Fernandes Ferreira nasceu em Santa Catarina, na ilha de Santiago, Cabo Verde, em 1924. Completou seus estudos secundários na cidade de Goa, em Panguim, capital do então chamado Estado da Índia Portuguesa, onde viveu por seis anos e concluiu os estudos do Magistério Primário. Seguiu para Lisboa em 1968, onde completou o Curso de Ciências Pedagógicas na Faculdade de Letras de Lisboa. Como esposa de diplomata, viveu em muitos lugares diferentes. Estas poucas informações evidenciam como, desde a biografia, a autora foi marcada por deslocamentos vários e assumiu literal e metaforicamente uma condição intelectual exilada.

Pode-se dizer que sua escrita se confunde bastante com um projeto nacional pós-independência que buscou traçar uma 
identidade cabo-verdiana que unisse a nação através da literatura. Uma escrita que não pretende, no entanto, ser apenas o espaço onde o indivíduo cabo-verdiano e sua situação no contexto mundial atual sejam problematizados; mas também como um dos possíveis espaços de representação e discussão da condição diaspórica e identitária desses sujeitos. Um espaço artístico, sobretudo, e com uma inserção peculiar na República das Letras. Para a escritora, é adequada a denominação de "traduzida", termo usado por Stuart Hall para falar de escritores migrantes:

Eles são o produto das novas diásporas criadas pelas migrações pós-coloniais. Eles devem aprender a habitar no mínimo, duas identidades, a falar duas linguagens culturais, a traduzir e negociar entre elas. ${ }^{1}$

Será a partir de conceitos de diáspora e de literatura menor que analisaremos alguns contos da escritora, contos "cujo universo literário é o dos emigrantes cabo-verdianos, um universo observado e participado no feminino", 2 expressão "da primeira diáspora africana em Portugal."33 Objetiva-se analisar o trânsito identitário que sofrem suas personagens a partir da experiência da diáspora, além de observar a crítica tecida ao lugar ocupado por essas personagens no cenário mundial.

O discurso sobre as novas diásporas tem hoje um lugar de destaque nas Ciências Humanas, o que se deve, entre outros fatores, ao adensamento da experiência da globalização e das trocas culturais muito mais intensas que ela promove. A questão que se coloca atualmente, até mesmo como um desafio, não se refere apenas ao contato com "outros" culturais diversos

${ }^{1}$ HALL, 1999, p. 89.

2 APA, 2009, p. 43.

${ }^{3}$ APA, 2009, p. 43. 
que nos obrigam a repensar significações rígidas do pensamento e da organização das sociedades; desenvolve-se também como uma busca conceitual que possa abranger novas maneiras de observar/conhecer o mundo. Assim, como quer Walter Moser, o grande desafio para a compreensão da cultura contemporânea, num mundo marcado pelas intensas "transferências culturais", é também de ordem epistemológica no sentido de que coloca observadores em situação de movência, tendo como objeto realidades culturais em trânsito.

Stuart Hall, por seu turno, acentua como as comunidades migrantes, ou seja, aquelas que constituem o que o estudioso vai chamar de culturas híbridas, ${ }^{5}$ vão exibir constitutivamente uma complexa feição híbrida e diaspórica, que confere dolorosas marcas às construções identitárias da pós-modernidade. São as identidades que Hall chama de traduzidas, ou seja:

(...) aquelas formações de identidades que atravessam e intersectam as fronteiras naturais, compostas por pessoas que foram dispersadas para sempre de sua terra natal. Essas pessoas retêm fortes vínculos com seus lugares de origem e suas tradições, mas sem a ilusão de um retorno ao passado. ${ }^{6}$

Veja-se que a reflexão elaborada por Hall é bastante adequada à comunidade cabo-verdiana, marcada pela emigração que a ela confere uma feição híbrida e uma identidade movente.

A intensificação dos processos contemporâneos de globalização promove, pois, as diásporas contemporâneas e cria espaços privilegiados para novas configurações culturais. Entendemos aqui o conceito de diáspora como definindo as

\footnotetext{
${ }^{4}$ MOSER, 2004.

${ }^{5}$ HALL, 1999, p. 88.

${ }^{6}$ HALL, 1999, p. 88.
} 
movimentações de grandes contingentes de pessoas nos dias atuais, motivadas por questões políticas, econômicas ou culturais. No seu livro Cartographies of diaspora: contesting identities, ${ }^{7}$ Avtar Brah reflete sobre as experiências diaspóricas da contemporaneidade, registrando que pensar esses movimentos transnacionais é imprescindível para uma análise das cartografias do mundo atual, promotoras de migrações e trocas intensas, pelo "encolhimento dos espaços" motivado pelas facilidades de deslocamento, pelas migrações forçadas, pelos deslocamentos motivados por conflitos políticos, étnicos etc.

Vários estudos atualmente vêm questionando visões dicotômicas dos espaços de produção de cultura, buscando tornar mais complexas suas relações. A.Brah nos diz da necessidade de pensar essas categorias sempre em relação a um dado referencial, relacional sobretudo se quisermos compreender as contradições que atravessam as negociações identitárias das chamadas minorias.

(...) 'minorities' are positioned in relation not only to 'majorities', but also with respect to one another, and vice versa. Moreover, individual subjects may occupy 'minority' and 'majority' positions simultaneously, and this has important implications for the formation of subjectivity. ${ }^{8}$

A citação acima explicita uma proposta de relativização das classificações rígidas que em geral fundamentam o que poderíamos chamar de pensamento hegemônico e pensamento das minorias, visto que um indivíduo ou cultura está em constante trânsito entre vários espaços, podendo ser considerado hegemônico ou minoritário dependendo das relações que estabelece com diferentes culturas e indivíduos.

7 BRAH, 1996.

${ }^{8}$ BRAH, 1996, p. 189. 
Nos estudos de literatura contemporânea, registra-se acentuado interesse por narrativas que privilegiam a interação cultural, como os relatos de viagem, a literatura de migração e a fala diaspórica. Além disso, vozes historicamente alijadas do cânone literário e marcadas pela experiência violenta da colonização são convocadas a compor novos lugares de enunciação, com o privilegiamento de um olhar periférico, promovendo a entrada em cena de narrativas construídas nos espaços das ex-colônias europeias, ou aquelas que intentam expressar esses mesmos espaços. A hegemonia da literatura canônica é também contestada por novas perspectivações sobre a produção literária mundial e pelo interesse por vozes vindas das margens do sistema cultural, não sendo tais deslocamentos, no entanto, sinônimo de harmonia no interior das trocas culturais, de resto, sempre marcadas por contradições e conflitos:

(...) a grande questão é o que fazer, nos imaginários postcoloniais, com o saber anti-colonial baseado numa oposição frontal, numa confrontação entre universos reconhecidos como outros. No espaço de língua portuguesa o diluir-se deste pensamento num conceito muitas vezes vago de hibridez ou mestiçagem, cancela a possibilidade de uma narrativa de alteridade finamente assumida como tal. Onde por alteridade entendo, cultura, raça, gênero e um termo um pouco fora de moda mas cada vez mais importante, classe social. ${ }^{9}$

O conceito de literatura menor, desenvolvido por Deleuze e Guattari, ${ }^{10}$ por seu turno, é particularmente fecundo ao incluir entre as possibilidades de leitura dessas produções o

9 APA, 2009, p. 47.

${ }^{10}$ DELEUZE/GUATTARI, 1977. 
sentido político de deslocamento da centralidade do cânone. Uma literatura menor seria aquela produzida por uma minoria social, mas escrita em uma língua que possui abrangência. Essa língua tem a desterritorialização como característica forte, ou seja, seus falantes/escritores não encontram nela sua origem ancestral, mas tomaram-na de empréstimo em algum momento da história, estranhando-a com sua dicção marginal. Além disso, a literatura menor é sempre política, expressando questões individuais, mas só o fazendo na medida em que essas representam um microcosmo do assunto universal que está sendo focalizado pelo texto literário. ${ }^{11}$ A literatura propõe-se, então, como enunciação coletiva, política e revolucionária, e sob essa definição podemos localizar, entre outras, as literaturas africanas e em especial, por ser este nosso objeto no presente texto, as literaturas africanas de língua portuguesa.

Como se sabe, a expressão literatura menor não designa apenas as literaturas das regiões ditas "das margens" do globo. Seria um conceito a ser aplicado a qualquer movimento "desterritorializante" que nasça dentro da literatura canônica, que a abale como parâmetro incontestável ou único. Consideraríamos, então, a escrita menor ou marginal como uma ferramenta, como um operador de leitura da produção literária: "Mesmo aquele que tem infelicidade de nascer no país de uma grande literatura, deve escrever em sua língua, como um judeu tcheco escreve em alemão, ou como um usbeque escreve em russo". ${ }^{12}$

A África se apresenta como continente marcado pela miséria e pela pouca atenção a ela dispensada pelo restante do mundo contemporâneo. $\mathrm{O}$ discurso a seu respeito ainda se dá, na maioria das vezes, pelo viés da tradição, dos rituais, do primitivismo. Por esse motivo, africanos têm experienciado a

${ }^{11}$ DELEUZE/GUATTARI, 1977, p. 27.

${ }^{12}$ DELEUZE/GUATTARI, 1977, p. 28. 
contemporaneidade principalmente através do choque entre as tradições e a globalização dos costumes, entre as diferentes violências decorrentes do sistema colonial e dos processos tardios de independência e de entrada "forçada" e inevitável no mundo globalizado. Isso acontece não só pela real importância da ancestralidade nas culturas africanas, mas também por ser esta a imagem exclusiva de África que por tantos séculos vem sendo exportada para o mundo ocidental: uma África cultural e politicamente atrasada, embora valorizada por seus exotismos. Em decorrência desse lugar que ocupa no mundo, a produção literária dos países africanos foi por muito tempo desconsiderada. Com a valorização dos hibridismos e das falas das minorias, no entanto - valorização contraditoriamente decorrente dos mesmos processos de globalização que secundarizam a África nas relações comerciais e econômicas -, as literaturas africanas começaram a conquistar espaço no ambiente acadêmico. JeanPaul Sartre já identificava, no prefácio que escreveu ao livro Os condenados da terra, de Frantz Fanon esse movimento de valorização das vozes antes excluídas da produção de conhecimento: "Numa palavra, o Terceiro mundo se descobre e se exprime por meio da voz". ${ }^{13}$

Podemos dizer que em Orlanda Amarílis, a língua, a construção identitária do intelectual e muitas das personagens representadas nos textos põem em discussão a pretensa harmonia da interação colonial e pós-colonial. Sua escrita se diferencia do cânone que o ex-colonizador representa através de marcas como a oralitura - termo que condensa a tradição literária escrita e a valorização performática da oralidade-,em uma contraditória mescla das culturas e tradições locais à tradição escrita que vem com o colonizador. Assim, o estilo peculiar de sua linguagem literária busca a expressão do

${ }^{13}$ FANON, 1979, p. 6. 
linguajar cotidiano de seus conterrâneos: a língua portuguesa mescla-se ao crioulo, às expressões e culinária locais, às interjeições que mimetizam a língua falada nas ruas pobres de Cabo Verde. Não se trata, no entanto, de mera "soma" de expressões nativas ou de referências a costumes e tradições folclorizados e a-históricos, acrescentados para dar uma cor local à escrita. Antes, trata-se de estranhar, de traduzir e se apropriar dos códigos culturais dominantes para criticamente evidenciar especificidade da posição diaspórica dessas enunciações, inclusive como resistência à descaracterização e à dominação cultural. Valem para os textos de Amarílis as palavras de Stuart Hall sobre o que chama de retorno do localismo:

Esse "localismo" não é um mero resíduo do passado. É algo novo - a sombra que acompanha a globalização: o que é deixado de lado pelo fluxo panorâmico da globalização, mas retorna para perturbar e transtornar seus estabelecimentos culturais. (...) Ele emerge em muitos locais, entre os quais o mais significante é a migração planejada ou não, forçosa ou denominada "livre", que trouxe as margens para o centro, o "particular" multicultural disseminado para o centro da metrópole cultural. ${ }^{14}$

O português culto, padrão é estranhado nas narrativas pela inserção do crioulo cabo-verdiano, uma tentativa de representar a linguagem falada, de marcar a escrita com os regionalismos. "Conchê!, porquê? Dondê? Só se for do tempo de chá de fedagosa. Sou mesmo disparatenta. ${ }^{15}$ [...] Oh nha mãe! Quem passasse por ele nesses momentos apanhava o seu chá. Bô também é trivide de pé-descalço. Sentá num cabo, sentá. ${ }^{16}$

\footnotetext{
${ }^{14}$ HALL, 2003, p. 61-62.

15 AMARILIS, 1974, p. 11.

${ }_{16}$ AMARILIS, 1974, p. 12.
} 
Como nos diz também Kobena Mercer, citada por Hall:

Numa gama inteira de formas culturais, há uma poderosa dinâmica sincrética que se apropria criticamente de elementos dos códigos mestres das culturas dominantes e os 'criouliza' desarticulando certos signos e rearticulando de outra forma seu significado simbólico. A força subversiva dessa tendência hibridizante fica mais aparente no nível da própria linguagem (incluindo a linguagem visual) onde o crioulo, o patois e o inglês negro desestabilizam e carnavalizam o domínio lingüístico do 'inglês'- a língua-mãe [nation-language] do metadiscurso - através de inflexões estratégicas, novos índices de valor e outros movimentos performativos nos códigos semântico, sintático e léxico. ${ }^{17}$

Veja-se no conto "Thonon-les-Bains", por exemplo, o diálogo entre duas vizinhas no qual é informada para o leitor a receita da "catchupa", prato cabo-verdiano típico. Entremeada por interjeições, performaticamente a receita mostra-se como lugar de resistência da tradição e, metaforicamente, da própria comunidade que, pelo menos pela palavra, supera a falta de alimento.

Esta dinâmica sincrética de que nos fala Mercer se dá pela via da apropriação carnavalizada, muitas vezes nos contos da escritora cabo-verdiana com personagens encenando o exílio no interior mesmo de Cabo Verde, desta feita frente ao mundo em modernização. Tal encenação se dá, por exemplo, no conto "Esmola de Merca", no qual as marcas de um espaço político são bem perceptíveis na crítica à "mente colonizada".

A jovem Titina é chamada para, junto com outras jovens, distribuir entre a população miserável a esmola que chega da América. Destacam-se personagens que pedem à menina que lhes separasse roupas de boa qualidade, mas que se recusam

${ }^{17}$ MERCER, apud HALL, 2003. p. 34. 
a tomar lugar na fila dos necessitados que se formaria em frente à Administração. Essas personagens buscam sua diferenciação dos pobres de seu país, em uma atitude que pode ser associada às da histórica da burguesia nativa de Cabo Verde, a qual representou o poder português nas ilhas durante o regime colonial, como classe mediadora do exercício do poder, e que se vê empobrecida depois da independência. A justificativa que separa Nhá Quinha daqueles que estão na fila pela esmola da América está baseada em seu anterior status de possuidora de bens e criados.

"Ir para a fila?" censurou-a. "Meter-se no meio do povo?" (...)

Nha Quinha nunca foi mulher de pedir de porta em porta. Ela foi dona da sua casa com tudo-em-quanto era preciso. Era criadas, era roupas penduradas no guarda-fato, era coisas boas no guarda-comida, era tudo, tudo. ${ }^{18}$

A reprodução do pensamento colonizado se apresenta novamente. O colonizado e a máscara do colonizador, diria Fanon: ${ }^{19}$ uma máscara que adere à pele do colonizado, tornandoo negativamente híbrido, na medida em que é, na esfera política, apenas um reprodutor da organização social da colonização.

Amarílis critica aqui a hibridização que se dá sob o signo de inferioridade atribuído aos cabo-verdianos, em sua interação com o mundo globalizado. Inferioridade esta que limita sua participação à cópia acrítica dos costumes ocidentais, sem a devida valorização do arcabouço cultural que trazem da terra. Para fortalecer a representação artístico-literária dessa hibridização negativa, a cena da distribuição das roupas americanas é

\footnotetext{
${ }^{18}$ AMARÍLIS, 1974, p. 52.

${ }^{19}$ FANON, 1952.
} 
descrita pelas personagens como "desfile das cores berrantes dos vestidos". ${ }^{20}$ Mulheres de todas as idades entravam no pátio da Administração em seus trapos mal-cheirosos para dali saírem vestidas em saias rodadas de cocktail, luvas, cachecóis, casacos trench-coat, sedas e chifons estampados. Os comentários entre as moças que distribuíam as esmolas chama a atenção:

“(...) Já reparaste, Julinha, já reparaste na figura desta gente dentro destas roupas para que não foi talhada? Oiá, oiá", e esticava os braços em direção da porta, "parece um desfile de carnaval. (grifos nossos)" ${ }^{21}$

Para essas imbricações presentes no espaço hibrído específico que são as ex-colônias europeias, H. Bhabha ${ }^{22}$ desenvolve o conceito de unhomely, ou "inabrigável". Da ordem do unhomely seriam as identidades desses indivíduos marcados pela violenta hibridização do colonialismo, que não se abrigam sob nenhuma significação rígida no que diz respeito ao seu lugar social no mundo.

Os contos de Amarílis, porém, não se atêm à relação entre cabo-verdianos e seus ex-colonizadores portugueses; antes, coloca-os frente a uma realidade ainda mais ampla e complexa, que é a diáspora, negociando suas constituições identitárias na interação com o mundo atual. Os processos diaspóricos atuais constituem, pois, um foco mais amplo e promissor a partir do qual analisar os contos de Orlanda Amarílis. Também a relação contraditória que tais personagens estabelecem com a terra natal e suas representações, chegando muitas vezes ao distanciamento e negação da pertença africana é tematizada nos contos da autora cabo-verdiana. O alcance de sua crítica e de suas

${ }^{20}$ AMARÍLIS, 1974, p. 58.

${ }^{21}$ AMARÍLIS, 1974, p. 57.

${ }^{22}$ BHABHA, 1992. 
representações alarga-se para a denúncia das desigualdades e desníveis do acesso aos bens do mundo globalizado.

A experiência da imigração na qual, como todos sabemos, se joga o grande discurso da cidadania do mundo contemporâneo, foge à experiência de retratar-se e de ser retratada, exatamente porque não considera, não se situa, dentro de um espaço que, longe de ser pacífico e homólogo, se rege sobre relações de força que tem que ser consideradas no seu existir. Dentro de um espaço que fala a mesma língua nem todos têm os mesmos direitos e para que alguém 'tome a palavra' é necessário criar a consciência de que a sua palavra é diferente dos outros mesmo que se expresse na mesma língua. ${ }^{23}$

Sua escrita possui, pois, uma dicção "exilada", estranhada já que o olhar que lança sobre seu país e sua cultura é crítico, possível apenas através do distanciamento que a assunção consciente e radical do exílio oferece. Seu exílio não é, no entanto, exclusivamente uma condição física de distanciamento do espaço natal, mas principalmente um pacto de leitura para uma linguagem e para um espaço criativo que querem erigirse nas e a partir das margens. Tal movimento se conjuga em sua obra a uma escrita em clave menor, que a investe de um tom político bastante crítico. Amarílis assume a posição revolucionária de instituir um lugar de fala para esses indivíduos tantas vezes invisíveis ou de voz mediada no discurso literário estabelecido, mas também a de questionar esses mesmos indivíduos. Assumindo uma voz localizada não só nas margens da literatura canônica, como também nas margens da sociedade global, ela retrata criticamente o impasse da posição ocupada pela África no mundo contemporâneo.

23 APA, 2009, p. 47. 
Poder-se-ia perguntar se o movimento da escrita de Amarílis seria apenas o de inserir o continente dentro de uma tradição ocidental, branca e masculina. Porém o apelo da sua escrita é antes de mais nada estrutural: questionar o lugar central dessa mesma tradição, propondo a coexistência, em suplemento (para usar a concepção desse termo proposta por Derrida em A escritura e a diferença) dessa tradição com outras visões de mundo. Uma coexistência pensada mais como desconstrução do que como harmonia ou integração sem conflitos.

As personagens de Orlanda Amarílis precisam adaptarse/resistir. Devem encontrar seu lugar dentro do mundo globalizado ocidental e questionar a centralidade desse mundo, forjando para si mesmas um espaço novo e condizente com a identidade híbrida de que são investidas. Ler a obra de Amarílis observando essas questões nos leva a um entendimento que amplia os horizontes de sua literatura, das outras literaturas africanas ou quem sabe até da grande maioria das outras literaturas provenientes das ainda denominadas margens da produção literária mundial. É possível perceber que há nelas uma força crítica de grande impacto, que guarda a possibilidade de deslocar a cultura hegemônica, em lugar de ambicionar apenas um espaço diminuído que as contemple no interior do cânone.

As personagens da escritora nos levam pelos caminhos não só do exílio na Europa, mas também de seu exílio da identidade cabo-verdiana, dada a força do elemento híbrido que permeia o trânsito desses indivíduos no processo de emigração. É o caso da protagonista do conto "Desencanto". Em oposição/complementaridade, outras personagens encenam o exílio no interior mesmo de Cabo Verde, desta feita frente ao mundo em modernização. Assim se vê no conto "Esmola de Merca". Na construção desses dois contos é possível perceber 
o que Avtar Brah ${ }^{24}$ concebe como diaspora space, ou seja, um espaço de imanência, mas também de intersecção, entre diáspora, margens e dis-location ("fora do lugar"). Funcionando a partir dessa intersecção estariam vários processos econômicos, políticos, culturais e psíquicos, que atuam na constituição do sujeito diaspórico. Uma concepção da sociedade, reitere-se, sempre modificada pela ótica dos movimentos diaspóricos atuais que colocam em contato regiões centrais e as margens do sistema. Veja-se, ainda, o conto "Thonon-les-Bains" no qual o casal de irmãos cabo-verdianos são "acolhidos" no Primeiro Mundo, como trabalhadores informais, "sem teto" e "sem papéis".

O seu trabalho no torno numa fábrica de esquis agradava-lhe sobremaneira. Descrevia em pormenor como apertava os parafusos, dava a volta aqueles paus informes, aparava-os, alindava-os à força de máquinas, desapertava os parafusos de novo e lá iam eles para outras mãos fortes para os polirem, depois para outras para lhes colocarem os ferros e assim por diante. A irmã estava no serviço de colar as etiquetas e dar uma limpeza final a cada esqui.

Não fiques apoquentada com esta conversa sobre o frio de Thonon, mamãe, porque mana também faz limpeza no hotel de manhãzinha muito cedo e a patrão deixa-nos dormir no caveau da escada no corredor onde tem um calorzinho sabe dia e noite..$^{25}$

Contrapõe-se o espaço ocupado por eles ao espaço do Ilhéu dos Pássaros, lugar da memória afetiva, dos costumes cabo-verdianos, mas também o espaço da carência e do sofrimento dos que se vêem obrigados a permanecer, sobretudo as mulheres idosas.

${ }^{24}$ BRAH, 1996.

${ }^{25}$ AMARÍLIS, 1982, p. 19. 
[...] "Sabe, comadre, a vida aqui já não podia continuar como era. Sete anos sem chuva é muito. Eu não tenho nem uma migalha de reforma de Deus - Haja. Nós vivemos da renda dos bocadinhos de terra e de mais alguma coisinha, encomendas dos nossos rendeiros, um cacho de banana de vez em quando, uns ovinhos, um balaio de magas uma vez por curta, uma quarta de mongolom, umas duas quartas de milho e é tudo."

"Eu também não tenho nada, comadre Ana. Se não fossem as flores para as coroas dos mortos ou umas rendinhas para lençol, como eu havia de governar, comadre?"

Nh'Ana concordava com a cabeça. "Sabe, comadre, se nhá fidja me mandar algum dinheirinho, posso começas um negócio de comidas, assim uma caldeira de catchupa com mandioca e toucinho para vender à boca- da- noite, um groguinho ou um pontche para emborcar em cima, e pronto." 26

Metaforizado na casa materna, o espaço de pertença constrói-se como estranhamente desterritorializado, um espaço transicional: entre a memória de um passado idealizado, uma "sôdade" da terra; um presente de penúria e perda; um entrelugar para o espaço do exílio. A morte violenta da moça emigrada pelo namorado europeu que não suporta vê-la exibirse na dança nativa de Cabo Verde põe um final trágico a qualquer possibilidade de integração ou de ingênuo "hibridismo" cultural, desmanchando o pretenso espaço integrativo do mundo globalizado e de aceitação das diferenças. Embora globalizados, dolorosamente nos mostram os contos de Amaralís, os mapas do mundo exibem diferenças e desequilíbrio conflitivos. Sintomático que a rejeição ao outro e à sua cultura se dê no corpo feminino, registrando, mais uma vez, como a

${ }^{26}$ AMARÍLIS, 1982, p. 14. 
questões de gênero são importantes para a reflexão sobre a diáspora africana suscitada pelos textos da autora.

O livro Cais do Sodré té Salamansa, publicado em 1974 é composto por sete contos, que se passam ora em Portugal, ora nas ilhas de Cabo Verde. Quase todas as personagens são caboverdianas, e uma grande parte delas vive a diáspora, seja aquela em que vivenciam a distância do solo pátrio, seja a diáspora que metaforiza um sentimento de perda ou distanciamento das tradições, do que se poderia chamar em algum momento de uma identidade cabo-verdiana, compartilhada pelos naturais daquela região e definida sempre em perspectiva. Essas personagens transitam pela obra de Amarílis retomando temas como a memória (única maneira possível de reviver a terra natal), o hibridismo cultural e o modo como, a partir da diáspora, o mundo contemporâneo será experienciado. Tudo isso marcado pela posição crítica que Amarílis assume - ela mesma uma intelectual diaspórica - ao pensar a maneira como se dá a complexificação das diferentes faces identitárias desses personagens. Ela é crítica também ao tratar da interação entre o local cabo-verdiano e o universal representado pelas culturas hegemônicas, denunciando a necessidade de repensar o lugar de minoria ocupado por seu povo e sua literatura.

Sendo o primeiro conto do livro intitulado "Cais do Sodré" (referência à estação de metrô de Portugal que faz a ligação com outras estações e com redes fluviais) e o último "Salamansa" (uma vila de pescadores na ilha de São Vicente), é possível pensar a obra em si como "uma viagem", um trânsito que busca fazer a ponte entre as representações da terra natal e as do exílio, passando por contos que expressam as tradições cabo-verdianas como "Rolando de nhá Concha" (que põe em evidência a visão que têm os cabo-verdianos da vida post-mortem), contos que encenam a experiência fora das ilhas ("Desencanto, "Cais do Sodré", "Nina"); e aqueles que traduzem as contradições existentes dentro da nação, como é o caso do 
conto "Esmola de Merca" ou "Canal Gelado", este último do livro Ilhéu dos pássaros.

As personagens de Amarílis, estando em exílio, contrapõem todo tempo a memória de sua identidade cabo-verdiana às modificações causadas pela distância espacial e temporal, distância que vai se inserindo nas suas filiações identitárias.

Em "Cais do Sodré", a cabo-verdiana Andresa espera pelo comboio na estação quando avista sua conterrânea Tanha. $\mathrm{O}$ cenário escolhido para o desenrolar da narrativa não é sem intenções: um lugar de passagem, em geral desinvestido de identificação com os indivíduos que por ali transitam. Andresa sente-se impulsionada a conversar com a mulher, mas após alguns minutos de conversa se dá conta de que já não se identifica com aqueles que vêm de sua terra, ao encontrá-los pelas ruas de Lisboa, ainda que tal sensação não ocorra sem uma boa carga de ambiguidade:

De há algum tempo para cá acontece-lhe isto. Vê um patrício, sente necessidade de lhe falar, de estabelecer uma ponte para lhe recordar a sua gente, a sua terra. Entretanto, feito o contacto, o desencanto começa a apoderar-se dela. Qualquer coisa bem no íntimo lho faz sentir. Não há afinidades nenhumas com as pessoas de há quinze anos atrás. Nem são as mesmas. ${ }^{27}$

Porém, tampouco se identifica com uma europeia com a qual divide um dos bancos da estação e nem é vista por esta última como "uma igual". Esse estranhamento pode ser percebido na descrição da personagem europeia, que insiste nas diferenças entre as duas mulheres, e na atitude posterior de Andresa, que decide acompanhar Tanha no comboio que está saindo da estação.

${ }^{27}$ AMARÍLIS, 1974, p. 15. 
Benjamin Abdala Júnior percebe essa personagem como "modelada pela língua, tornando-se uma atriz que expressa a sua maneira de ser enquanto produto originário de duas culturas". ${ }^{28}$

Após sair de Cabo Verde, Andresa já não é a mesma, e desencanta-lhe pensar na distância que agora a separa dos conterrâneos. Desencanto este semelhante ao vivido pela protagonista sem nome do conto significativamente denominado "Desencanto", que será abordado posteriormente.

Benjamin Abdala Júnior inicia seu artigo "Orlanda Amarílis, literatura de migrante" referindo-se à Pasárgada de Manoel Bandeira, ao sonho ou idealização de um espaço de bem estar e satisfação dos desejos. Segundo o crítico, Orlanda Amarílis assume perspectiva inversa à do escritor brasileiro: rejeita o patriarcalismo libertino de Pasárgada, investindo sua escrita de um caráter feminino e que levanta outra bandeira, a da pertença a uma nação. O crítico se refere ainda à concepção que Maria Aparecida Santili defende a respeito da escrita de Amarílis como sendo marcada por "voltas delicadas para fundir o que 'era' no que 'é' cabo-verdiano". ${ }^{29}$ Tece, assim, a autora, uma rede de traços identitários que delineariam a experiência da diáspora. Santilli enuncia também a linguagem das "mulheres contidas" ou das mulheres-sós, universais e alijadas da fala em "sociedades masculinas" ao redor do globo. Os contos de Amarílis, assim perpassados por vozes femininas, exibem construção literária fortemente marcada pela "maneira de ser cabo-verdiana", ${ }^{30}$ com uma perspectiva de gênero.

${ }_{28}$ ABDALA JÚNIOR, 1999, p. 81.
${ }^{29}$ ABDALA JÚNIOR, 1999, p. 79.
${ }_{30}$ ABDALA JÚNIOR, 1999, p. 81. 
Já o teórico português Pires Laranjeira, em "Mulheres, ilhas desafortunadas", entende a diáspora como cenário, que compreende a grande cidade onde a "sôdade" se instala e onde se tecem "redes de cumplicidade". Essas redes são as que tece Andresa, por exemplo, sem compreender muito bem o porquê, ao não conseguir deixar de dirigir a palavra aos que como ela vêm das ilhas e agora caminham por Lisboa, impulso que se mistura à vontade de se afastar desses mesmos conterrâneos.

Um elemento que se destaca na produção acadêmica acerca da obra de Orlanda Amarílis é a multiplicidade de sentidos que a diáspora incorpora: ela é tida como experiência concreta das personagens, que migram; como cenário onde as identidades se misturam e se ressignificam; como representações de deslocamento investidas de sentido político (os deslocamentos que promovem a interação de espaços separados pela ordem mundial vigente, que separa o centro das margens); como fundante de uma epistemologia - o olhar exilado da autora, em consonância com a ideia de intelectual no exilio, o "out of place", de Edward Said. ${ }^{31}$ Muito embora não seja objetivo da literatura representar fielmente a realidade social, essa realidade encontra ecos no texto literário: o texto apropria-se dela, reinventandoa, resignificando-a.

Em Cais do Sodré té Salamansa, livro publicado em 1974, alternam-se contos narrados a partir do exílio e outros que se passam nas ilhas e que nos falam das tradições e crenças, como a proximidade entre os mortos e os vivos em "Rolando de nhá Concha". Esse conto aproxima o leitor das crenças da terra, e a narrativa por vezes assemelha-se às histórias do imaginário popular, com personagens do povo brigando por ninharias e com a ambiência nas ilhas. O espaço cabo-verdiano construído no conto é pobre, empoeirado ("rua estreita e suja de pó de

${ }^{31}$ SAID, 1994. 
carvão", a "praça de terra avermelhada", as "casas de primeiro andar", a "terra seca e vermelha") e aparece problematizado com a presença de diferentes vozes e focos narrativos, com referências à emigração e à situação de penúria dos caboverdianos de extração humilde. As vozes que se cruzam, contrapondo-se, alternando-se com "a voz" do morto, falam dos períodos de seca, da fome, e do sofrimento da população que acaba por emigrar em busca de oportunidades. Esse deslocamento físico, tão presente na história do país e retratado em outros contos da autora que abordam a vida do emigrado, aparece também neste conto que se passa em Cabo Verde.

Oh, tão bom embarcar, sair, soltar - se da prisão da ilha onde sempre vivera. Fugir daquele sol crã. Esse sol crestava a grama solta pelas achadas áridas e avermelhava mais ainda o descampado de Chã de Alecrim, da Chã de Cemitério. Esse sol secava os poços de água salobra e tornara cor de café torrado a sua [de Rolando] tez de mestiço. Ah, embarcar, evadir-se para além do elo que torneava e sufocava a ilha agreste. ${ }^{32}$

Veja-se como se faz a descrição da farinha vinda da América, entremeada à descrição dos pratos típicos da terra e ao diálogo com o leitor que, retoricamente, é indagado, entrando nas considerações do narrador, inclusive as de ordem ética, sobre a terra natal e suas formas de fugir à fome.

Gold meal é uma farinha tão branquinha e tão fina, gente. Mandam-na da América. Também mandam farinha de milho. Com farinha de milho fazemos fongos assados na brasa quente fazemos brinholas amassadas com banana madura, banana platcha apanhada no pelourinho da loja de nha Carlota e noutros lugares mais onde se vende fruta. Nós só apanhamos a fruta muito madura, é preciso compreender. Nós não roubamos não Senhor. Só a apanhamos, só a chocamos. É pecado chocar uma banana para aparar a 
fraqueza do nosso estômago? Ah! Também nos mandam leite em pó banha roupa. ${ }^{33}$

O pronome "nós" faz do narrador o mediador de uma voz coletiva, também presente nas marcas de oralidade, com o uso do diminutivo ("Depois de um groguinho uma pessoa fica mais consertada não é? E com este calor, uma pinga refresca sempre.") com expressões tiradas ao quotidiano ( "Ó li leite! Leite para pôr no café! Ó li leite"!)com perguntas retóricas que contribuem para o processo de interação ("É pecado chocar uma banana para aparar a fraqueza do nosso estômago? Ah! Também nos mandam leite em pó banha roupa.") e muitos outros recursos.

Outro tom é encontrado no conto "Salamansa", que encerra o livro. Trata-se de um relato narrado na perspectiva de um cabo-verdiano de posses, Baltasar, que permaneceu em Cabo Verde. Baltasar assiste à partida daqueles que o rodeiam, incluindo a mulher que amava, a prostituta Linda. $\mathrm{O}$ homem questiona o êxodo, representando aqueles que apesar de não serem levados à diáspora pela necessidade, experimentam a solidão na terra natal, produzida pelo exílio daqueles a quem amam. O conto termina com uma cantiga em crioulo, melancólica e pungente, reverenciando as paisagens de Salamansa, tão vazias e abandonadas.

O conjunto das sete histórias faz, pois, movimentos de saída e retorno às ilhas de Cabo Verde, por meio das recordações, da memória, seja ela individual ou coletiva, o mais das vezes ambas as condições, o social entranhando-se no drama pessoal e familiar. A esse respeito, é pertinente a análise que Pires Laranjeira faz do narrador-mor dos contos, "pai de sete narradores, em cada conjunto de histórias, [que] vive na

${ }^{32}$ AMARÍLIS, 1974, p. 28. 
diáspora, vivendo de recordações" ${ }^{34}$ Este viver de recordações nos coloca frenteà importância da memória para essas personagens, pois é apenas através dela que é possível trazer para o presente, de alguma forma, a sua terra natal.

A memória não é vista, portanto, como um simples conjunto de armazenadas informações do passado, como nostalgia de um espaço de pertença sem recuperação possível. Antes, é o lugar de criação de imagens, de idealização e de conexão com o presente, modificando a maneira como o enxergamos, operando também na situação oposta (o presente também modifica a maneira como nos relacionamos com o passado) e alterando os signos que ligam os personagens à terra. Assim ela funcionaria para todos nós, e em especial para os indivíduos diaspóricos. No conto "Nina", o narrador caboverdiano em diáspora reconstrói pela memória sua relação com Nina, a moça branca com quem teve um breve e tumultuado relacionamento. Ele se questiona se ela partilharia a mesma memória que ele, agora que finge que não o vê ao passar pela estação de comboios onde ele se encontra. Outros exemplos da recorrência da memória são abundantes em vários contos de Amarílis: Rolando de nhá Concha relembrando toda a sua vida de maneira caótica até perceber-se já morto; Andresa na gare recontando para si histórias de São Vicente em "Cais do Sodré"; Baltasar recordando seu relacionamento com a prostituta Linda em "Salamansa"; as mulheres famintas de "Esmola de Merca" recriando pela memória períodos de abundância. Assim como estas, várias outras personagens expressam uma memória que apenas em parte constitui-se dos fatos "vividos", mas que terminam por formar para nós leitores uma grande memória compartilhada por esses indivíduos como coletividade. Uma memória das ilhas, escrita pelos que se sentem (ou realmente estão) exilados de seu país. Exilados, pois o exílio mostra-se um estado intermediário, a condição do indivíduo que não está em consonância nem com seu país de origem, nem com o lugar 
onde se encontra, que vê-se instado a flutuar entre as modificações que o exílio opera e a nostalgia de não poder reviver o espaço deixado, a não ser por essa memória fluida, sempre ressignificada, traduzida. As personagens de Orlanda Amarílis não ambicionam voltar para as ilhas, e sim integrar-se a um espaço cultural mais amplo, globalizado. O território natal persiste, no entanto, como a vivida/vívida lembrança, a marca indelével da identificação cultural pátria. Revelam-se como formações identitárias em constante "negociação" já que:

(...) são obrigadas a negociar com as novas culturas em que vivem, sem simplesmente serem assimiladas por elas e sem perder completamente suas identidades. Elas carregam os traços das culturas, das tradições, das linguagens e das histórias particulares pelas quais foram marcadas. A diferença é que elas não são e nunca serão unificadas no velho sentido, porque elas são, irrevogavelmente, o produto de várias histórias e culturas interconectadas, pertencem a uma e, ao mesmo tempo a várias "casas" (e não a uma "casa" particular). ${ }^{35}$

No conto "Desencanto", encontramos a metáfora do trânsito identitário na viagem da protagonista cabo-verdiana imigrante em Lisboa, de seu local de residência até o trabalho. $\mathrm{O}$ transitar dessa protagonista metaforiza o caminho que os cabo-verdianos exilados percorrem: saem das ilhas para a Europa em busca de sustento, não sendo por acaso que o trânsito se dê em direção ao trabalho. Segundo o sociólogo Pierre Bourdieu, ${ }^{36}$ o imigrante só possui uma identidade no e

${ }^{33}$ AMARÍLIS, 1974, p. 29.

${ }^{34}$ PIRES LARANJEIRA apud ABDALA JÚNIOR, 1999, p. 79.

${ }^{35}$ HALL, 1999, p. 88-89.

36 BOURDIEU, 1998. 
pelo trabalho que desempenha. É essa, então, a maneira como se dará a entrada do imigrante cabo-verdiano no mundo globalizado contemporâneo. Mas ele o faz pela "porta dos fundos", atrás dos balcões, desempenhando funções desconsideradas e desprezadas pelos nativos europeus, indo somente até onde sua condição de ex-colonizado e exilado permitir. Orlanda Amarílis critica esse veio de entrada no mundo moderno ocidental, caracterizado pelo sinal negativo atribuído aos cabo-verdianos e aos imigrantes africanos em geral. A protagonista do conto reconhece o preconceito que sofre pela sua origem:

Ninguém tem culpa de ser como é. Pena era as pessoas não entenderem a lhanesa que ela e as patrícias punham no trato e daí uma série de qüiproquós comprometedores e acabando por as deixar mal vistas. A elas pelo menos tem sido a sua sina. Saía de uma para se meter noutra. ${ }^{37}$

Configura-se na passagem acima, além disso, o preconceito dirigido às mulheres cabo-verdianas, evidenciando como as questões de gênero marcam profundamente a escrita da autora.

O trânsito pelo espaço físico é motor de partida para o trânsito identitário pretendido pela protagonista do conto. Ela busca integrar-se à cidade de Lisboa, assumir uma outra configuração identitária na sociedade portuguesa, o que deixa claro mais à frente ao dizer que buscava afastar-se de outros cabo-verdianos que encontrava na cidade portuguesa, justamente para (e o conto desmancha perversamente esta pretensão) confundir-se com outros portugueses, tornando "invisível" sua cabo-verdianidade.

A cidade pela qual transita é impessoal, formada por pessoas em movimento constante as quais ela identifica por

${ }^{37}$ AMARÍLIS, 1974, p. 42. 
algumas características físicas ou pelos gestos e falas maquinais do dia-a-dia, formando um quadro típico das grandes cidades. Mas mesmo nessa cidade, onde rostos são fugazes e são poucos os que recebem nomes próprios, a protagonista é forçada a se deparar com a sua condição de imigrante e, principalmente, de hibridismo identitário resultante da colonização:

O homem do chapéu preto está junto dela. Pressente-o pelo faro que já tem dessas aproximações.

Um susurro fá-la estar atenta.

"Estás bom, pá?"

"Malandro, estás a fazer-te pra mulata."

Riem baixo e esse riso é uma afronta.

"Bom dia, passou bem?"

Desce trêmula, pisando os degraus com atenção.

Encruzilhada pela qual tem que escolher. Sempre a fugir de andar com os patrícios de cor para não a confundirem e afinal é um branco que lhe vem lembrar a sua condição e mestiça. ${ }^{38}$

O discurso sobre a inevitabilidade dessa dupla pertença identitária pós-colonial, especialmente na situação de exílio, encontra-se claramente exposto. A personagem desencanta-se com a possibilidade de adentrar de outra forma a cultura global atual, a não ser como estrangeira mulata e principalmente trazendo no corpo, na cor da pele e na sua condição de mulher as marcas da disponibilidade sexual. Se já não é cabo-verdiana, também não poderá desvencilhar-se dos fragmentos da tradição materna, da marca nacional e da condição que a torna objeto à disposição do olhar de desejo do português / colonizador. $\mathrm{O}$ encanto de se pensar plenamente assimilada pelo ritmo da grande cidade portuguesa se desfaz no chamamento "mulata":

${ }^{38}$ AMARÍLIS, 1974, p. 45. 
aquele branco lembra-lhe sua hibridez, através da cor da pele. Que seja através da cor da pele tampoucoé um acaso: no sistema colonial, mais que em qualquer outro traço, a identidade de um indivíduo estava irremediavelmente ligada à cor de sua pele. O homem não a lembra, então, somente de sua hibridez, mas também de sua condição de minoridade, de posição de inferioridade social dentro daquele sistema. A conclusão do narrador, fechando o conto, evidencia a inclassificável identidade da mulher cabo-verdiana: "Oh céus! É uma cigana errante, sem amigos, sem afeições, desgarrada entre tanta cara conhecida." 39

Entretanto, a crítica maior de Orlanda Amarílis se faz sentir quando seu objeto é o próprio sujeito cabo-verdiano e não a sociedade ocidental atual. Intelectual em posição de exílio que é, a autora distancia-se o suficiente da cultura a que deveria filiar-se naturalmente, para criticá-la.

A protagonista do conto, por seu turno, contribui para sua posição subalterna na ordem mundial, ao buscar espaço nela por meio da negação de sua cultura e de sua cor, tentando adaptarse em lugar de promover mudanças. Posiciona-se como mente colonizada, mente esta que Frantz Fanon busca explicar:

O olhar que o colonizado lança sobre a cidade do colono é um olhar de luxúria, um olhar de inveja. Sonhos de posse. Todas as modalidades de posse: sentar-se à mesa do colono, deitar-se no leito do colono, com a mulher deste, se possível. O colonizado é um invejoso. ${ }^{40}$

Fanon tece sua crítica a respeito do sujeito que, uma vez colonizado, não se posiciona na luta contra a configuração subalterna de pensamento que lhe foi imposta pelo colonizador europeu. E é esta também a natureza do olhar crítico que

\footnotetext{
39 AMARÍLIS, 1974, p. 45.

${ }^{40}$ FANON, 1979, p. 29.
} 
Orlanda Amarílis lança sobre sua personagem, representação microcósmica que é dos próprios emigrantes cabo-verdianos em solo europeu. Sua crítica aponta talvez para a necessidade de que esses indivíduos, frutos da colonização e, posteriormente, do exílio, assumam de maneira consciente e pró-ativa sua posição de hibridez no mundo contemporâneo, e que a partir dessa posição - e não da posição de minoria assimilada localizem-se neste mundo, não necessariamente sob a égide da hegemonia do pensamento ocidental.

Entramos aqui, então, na percepção do indivíduo como sendo moldado dentro da interseção proposta por A. Brah: ${ }^{41}$ sua condição diaspórica, o lugar de margem de onde seu discurso procede, e o "fora de lugar" próprio de sua identidade (inclusive historicamente). A articulação que Amarílis faz desses pontos leva a uma relação entre eles e as condições globais de cultura, economia e política. Abre-se um espaço, então, para que essas três instâncias sejam pensadas através da migrância, da viagem.

Orlanda Amarílis e suas personagens: literatura menor, literatura da diáspora.

\section{Referências bibliográficas}

ABDALA JÚNIOR, Benjamin. Orlanda Amarílis, literatura de migrante. Dossiê Via Atlântica. São Paulo, n.2, p.76-89, jul.1999.

AMARÍLIS, Orlanda. A Casa dos Mastros. Linda-a-Velha, ALAC, 1989. AMARÍLIS, Orlanda. Cais do Sodré té Salamansa. Lisboa: Bertrand, 1974.

AMARÍLIS, Orlanda. Ilhéu dos Pássaros - Lisboa: Plátano, 1982.

${ }^{41}$ BRAH, 1996. 
ANDERSON, Benedict. Comunidades Imaginadas: reflexões sobre a origem e a difusão do nacionalismo. São Paulo: Companhia das Letras, 2008.

APA, Lívia. Uma diáspora muda? Cartografias, evocações e afasias na narrativa da diáspora em língua portuguesa. In: GROSSEGESSE, Orlando; THORAU, Henry. À procura da Lisboa africana: da encenação do império ultramarino às realidades suburbanas. Braga: Universidade do Minho/Centro de Estudos Humanísticos, 2009. p. 41-49.

BHABHA, Homi. O local da cultura. Trad. Myriam Ávila, Eliana Lourenço de Lima Reis, Gláucia R. Gonçalves. Belo Horizonte: UFMG, 1998.

BOURDIEU, Pierre. Prefácio. In: SAYAD, Abdelmalek. A Imigração: ou os paradoxos da alteridade. Trad. Cristina Murachco. São Paulo: EDUSP, 1998.

BRAH, Avtar. Diaspora, border and transnational identities. In: Cartographies of diaspora: contesting identities. London Routledge, 1996.

DELEUZE, Gilles; GUATARRI, Félix. Trad. Júlio Castañon Guimarães. Kafka: por uma literatura menor. Rio de Janeiro: Imago, 1977.

DERRIDA, Jacques. A escritura e a diferença. São Paulo: Perspectiva, 1971.

FANON, Frantz. Os condenados da terra. Trad. Laurênio de Melo. 2. ed. Rio de Janeiro: Civilização Brasileira, 1979.

FIGUEIREDO, Eurídice (Org.). Conceitos de literatura e cultura. Juiz de Fora: UFJF; Niterói: UFF, 2005.

HALL, Stuart. A identidade cultural na pós-modernidade. 3. ed. Trad. Tomaz Tadeu da Silva. Rio de Janeiro: DP\&A, 1999.

HALL, Stuart. Da diáspora: identidades e mediações culturais. Trad. Adelaine La Guardia Resende et al. Belo Horizonte: UFMG; Brasília: UNESCO, 2003. 
MOSER, Walter. La culture en transit: locomotion, médiamotion, artmotion. Gragoatá: Revista do Programa de Pós-graduação em Letras, n. 17, p. 25-41, 2004.

PIRES LARANJEIRA, J. L. Mulheres, ilhas desafortunadas. Prefácio a AMARÍLIS, Orlanda. A casa dos mastros. Lisboa: ALAC, 1989.

SAID, Edward W. Representação do Intelectual: as Conferências Reiht de 1993. São Paulo: Companhia das Letras, 2005.

SANTILLI, Maria Aparecida. As mulheres-sós de Orlanda Amarílis. In: Africanidade. São Paulo: Ática, 1985.

\section{Resumo}

Este ensaio contempla as representações identitárias caboverdianas presentes nos contos da escritora Orlanda Amarílis e como tais representações se inserem em um projeto crítico da autora. Os movimentos diaspóricos das personagens transformam suas configurações identitárias, e o modo como elas são construídas revela um profundo questionamento a respeito do lugar que os cabo-verdianos e a literatura proveniente de Cabo Verde ocupam no cenário mundial.

\section{Abstract}

This paper contemplates the Cape Verde representations of identities present in the short stories of the writer Orlanda Amarilis, and in which ways these representations are introduced in a critical project of the author. The diasporic movements of the characters turn their identities' configurations, and the way they are built reveals a profound questioning about the place in which the Cape Verdeans and the literature from Cape Verde occupy the world scenery. 